\title{
Kinetics of intermetallic phase growth and determination of diffusion coefficients in solid- solid-state reaction between $\mathrm{Cu}$ and $(\mathrm{Sn}+1 \mathrm{at} . \% \mathrm{Ni})$ pads
}

\author{
A. Wierzbicka-Miernik ${ }^{1, \star}$, K. Miernik ${ }^{2}$, R. Filipek ${ }^{3}$, and K. Szyszkiewicz ${ }^{3}$ \\ ${ }^{1}$ Institute of Metallurgy and Materials Science, Polish Academy of Sciences, 25 Reymonta Str, 30-059 Kraków, Poland \\ ${ }^{2}$ Institute of Materials Engineering, Cracow University of Technology, 37 Jana Pawla II Av, 31-864 Kraków, Poland \\ ${ }^{3}$ Faculty of Materials Science and Ceramics, AGH University of Science and Technology, 30 Mickiewicza Av, 30-059 Kraków, Poland
}

Received: 29 January 2017

Accepted: 8 May 2017

Published online:

22 May 2017

(C) The Author(s) 2017. This article is an open access publication

\begin{abstract}
The influence of nickel addition to tin substrate on microstructure, kinetics parameters as well as diffusion coefficients was studied on $\mathrm{Cu} / \mathrm{Sn}$ diffusion couples. The results revealed that the presence of nickel did not affect the growth of $\mathrm{Cu}_{3} \mathrm{Sn}$ phase in comparison with that of the binary $\mathrm{Cu} / \mathrm{Sn}$ diffusion couple. However, it substantially influenced the morphology and chemical composition of the $\left(\mathrm{Cu}_{1-x} \mathrm{Ni}_{x}\right)_{6} \mathrm{Sn}_{5}$ phase, which grew with dual morphology and different chemical composition. The layer of the phase was poorer in nickel, whereas detached grains were richer in nickel concentration. The calculated kinetic parameters showed that the growth of the $\mathrm{Cu}_{3} \mathrm{Sn}$ and Ni-poor $\left(\mathrm{Cu}_{1-x} \mathrm{Ni}_{x}\right)_{6} \mathrm{Sn}_{5}$ phases was controlled by volume diffusion, but in the case of Nirich $\left(\mathrm{Cu}_{1-x} \mathrm{Ni}_{x}\right)_{6} \mathrm{Sn}_{5}$ phase, the growth was controlled by a complex mechanism. The calculations of diffusion coefficients and activation energies of $\mathrm{Cu}_{3} \mathrm{Sn}$ and Ni-poor $\left(\mathrm{Cu}_{1-x} \mathrm{Ni}_{x}\right)_{6} \mathrm{Sn}_{5}$ phases revealed that the presence of nickel in the tin substrate did not affect the rate of formation/growth of those phases in comparison with the binary $\mathrm{Cu} / \mathrm{Sn}$ diffusion couples.
\end{abstract}

\section{Introduction}

The development of the basic knowledge in the field of phase transformations in the $\mathrm{Cu}-\mathrm{Ni}-\mathrm{Sn}$ ternary system considered as one of the most important in the soldering has an extra meaning for the implementation of new lead-free materials [1-7]. The intermetallic phases growing at the interface of under-bump metallization and solder strongly affect the electro-mechanical properties of the final product. Copper and nickel are the main components of the metallized layer [8-11], while tin is the key constituent of the lead-free solders. Therefore, the careful analysis of structural changes, supplemented with kinetics description of the process occurring during the interaction between $\mathrm{Ni}, \mathrm{Cu}$ and $\mathrm{Sn}$, is very important from the application point of view [12-14].

Address correspondence to E-mail: a.wierzbicka@imim.pl; wierzbickamiernik@gmail.com 
Previous studies have shown that even relatively small amount of $\mathrm{Ni}$ (up to 5 at.\%) added to a copper substrate strongly affected the microstructure of the $(\mathrm{Cu}, \mathrm{Ni}) / \mathrm{Sn}$ reaction zone $[15,16]$. In a classical $\mathrm{Cu} /$ Sn diffusion couple, the $\eta\left[\mathrm{Cu}_{6} \mathrm{Sn}_{5}\right]$ phase formed first, and then the growth of $\varepsilon\left[\mathrm{Cu}_{3} \mathrm{Sn}\right]$ phase took place. The addition of even 1 at.\% of $\mathrm{Ni}$ to $\mathrm{Cu}$ causes the appearance of $\left(\mathrm{Cu}_{1-x} \mathrm{Ni}_{x}\right)_{6} \mathrm{Sn}_{5}$ phase together with $\varepsilon\left[\mathrm{Cu}_{3} \mathrm{Sn}\right]$. Further addition of $\mathrm{Ni}(5 \mathrm{at} \%)$ blocks the growth of $\varepsilon\left[\mathrm{Cu}_{3} \mathrm{Sn}\right]$ phase to such an extent that only $\left(\mathrm{Cu}_{1-x} \mathrm{Ni}_{x}\right)_{6} \mathrm{Sn}_{5}$ is present in the reaction zone $[15,16]$. Additionally, in the case of the $(\mathrm{Cu}, \mathrm{Ni}) / \mathrm{Sn} /(\mathrm{Cu}, \mathrm{Ni})$ diffusion-soldered joints, the nickel addition to copper significantly affects the morphology of the $\left(\mathrm{Cu}_{1-x} \mathrm{Ni}_{\mathrm{x}}\right)_{6} \mathrm{Sn}_{5}$ phase, so that it does not grow as a continuous layer but it spreads in the form of many individual grains. Further annealing causes their agglomeration, and finally, they join together to create the layer [15]. Moreover, the nickel addition to copper leads to such a change in the diffusion mechanism that the phase transformations occurring in diffusion couples accelerate by about an order of magnitude [17]. However, the practical implementation of the nickel addition to copper may be challenging. Therefore, the present research is devoted to the study of the influence of nickel addition to tin on the diffusion phenomena and growth mechanism of the intermetallic phases at the $\mathrm{Cu} /(\mathrm{Sn}, \mathrm{Ni})$ interface, being much more easy to apply in the production line. Although there are reports related to the nickel addition to lead-free solders such as $\mathrm{SAC}(\mathrm{SnAgCu})$ alloy, they are associated rather with the technological aspects [18].

\section{Experimental}

The $(\mathrm{Sn}, \mathrm{Ni})$ and $\mathrm{Cu}$ substrates used in the diffusion couple experiment were prepared using pure metals: Sn 99.998\%, Ni 99.99\% and Cu 99.99\% (Alfa Aesar). The appropriate amounts of pure metals were melted in vacuum induction furnace (Leybold-Heraeus) under argon protective atmosphere $(0.03 \mathrm{MPa})$ to obtain the $(\mathrm{Sn}, \mathrm{Ni})$-based alloys with 1 at. $\%$ of $\mathrm{Ni}$ and $\mathrm{Cu}$. Then, the cast alloys were cut into $3 \mathrm{~mm}$ thick pads. Before the diffusion couple experiment, the surfaces of the $(\mathrm{Sn}+1 \mathrm{at} . \% \mathrm{Ni})$ and $\mathrm{Cu}$ substrates were ground with the paper of 2000 maximum gradation and then cleaned with acetone in an ultrasonic washer. The prepared pads were pressed, sealed in quartz ampoules and subjected to annealing at 200, 215 and $220{ }^{\circ} \mathrm{C}(473,488$ and $493 \mathrm{~K})$ for $48,120,168$ and $225 \mathrm{~h}$ followed by cooling with the furnace for an appropriate time interval.

The obtained diffusion couples were subjected to detailed microstructure and chemical composition characterization using scanning electron microscope JEOL JSM 5510 LV equipped with an energy dispersive X-ray spectrometer (EDS), IXRF Model 500.

In order to perform the growth kinetics analysis and diffusion coefficient calculations, the thicknesses $(\Lambda)$ of the intermetallic $\mathrm{Cu}_{3} \mathrm{Sn}$ and Ni-poor $\left(\mathrm{Cu}_{1-x} \mathrm{Ni}_{\mathrm{x}}\right)_{6} \mathrm{Sn}_{5}$ phases, which were formed more or less as layers, were measured after different temperatures and times of annealing, using the specialized computer program-R-Tools, written in Borland Delphi 6.0 [19]. Its operation is based on the analysis of the imported image of the microstructure obtained in the scanning electron microscope. The interface between $\mathrm{Ni}$-rich and $\mathrm{Ni}$-poor variants of $\left(\mathrm{Cu}_{1-x} \mathrm{Ni}_{\mathrm{x}}\right)_{6} \mathrm{Sn}_{5}$ phase was indistinguishable during ordinary observations using backscattered electrons mode (BSE). Therefore, the thickness of Ni-poor $\left(\mathrm{Cu}_{1-x} \mathrm{Ni}_{x}\right)_{6} \mathrm{Sn}_{5}$ phase variant was chosen based on the EDS line scans made across the reaction zone between the $\mathrm{Cu}$ and $(\mathrm{Sn}, \mathrm{Ni})$ substrates in many different places of the sample. Due to the irregular growth of the phases, at least 3 different photographs, taken at the same magnification, were used for the analysis. The average of 20 independent measurements of thickness was made for each image. The arithmetic average of the phase thicknesses and the standard deviations of measurements were calculated. The stereological analysis using the software ImageJ by Wayne Rasband $1.45 \mathrm{~s}$ from the National Institutes of Health, USA, was carried out in the case of the $\left(\mathrm{Cu}_{1-x} \mathrm{Ni}_{\mathrm{x}}\right)_{6} \mathrm{Sn}_{5}$ phase formed as irregular grains (Ni-rich variant) $[17,20]$, to obtain quantitative information about the phase area. Based on this analysis, the determination of the growth kinetics parameter for this variant of the $\left(\mathrm{Cu}_{1-\mathrm{x}} \mathrm{Ni}_{\mathrm{x}}\right)_{6} \mathrm{Sn}_{5}$ phase was performed.

\section{Results and discussion}

\section{Microstructure and chemical composition analysis}

Studies of the microstructure and chemical composition of the $\mathrm{Cu} /(\mathrm{Sn}+1 \mathrm{at} . \% \mathrm{Ni})$ diffusion couples 
were performed for the samples annealed at 200, 215 and $220{ }^{\circ} \mathrm{C}(473,488$ and $493 \mathrm{~K})$ for $48,120,168$ and $225 \mathrm{~h}$ (2, 5, 7, 9.3 days), using scanning electron microscope (SEM). The examples of the SEM microstructures of the obtained cross sections of samples and the phase identifications are presented in Fig. 1.

The chemical composition analysis with SEM/EDS technique revealed the presence of three intermetallic phases (IMPs): $\mathrm{Cu}_{3} \mathrm{Sn},\left(\mathrm{Cu}_{1-x} \mathrm{Ni}_{\mathrm{x}}\right)_{6} \mathrm{Sn}_{5},\left(\mathrm{Ni}_{1-x} \mathrm{Cu}_{x}\right)_{3} \mathrm{Sn}_{4}$ (Fig. 1), due to the interdiffusion of elements across the interface. The $\left(\mathrm{Ni}_{1-\mathrm{x}} \mathrm{Cu}_{\mathrm{x}}\right)_{3} \mathrm{Sn}_{4}$ phase appeared as a result of the copper diffusion into $\mathrm{Ni}_{3} \mathrm{Sn}_{4}$ grains dispersed in the $\left(\mathrm{Sn}+1\right.$ at.\%Ni) substrate. The $\mathrm{Ni}_{3} \mathrm{Sn}_{4}$ phase was present in the $(\mathrm{Sn}+1 \mathrm{at} . \% \mathrm{Ni})$ pad before the experiment of diffusion couples (Fig. 2). The microstructure of $\mathrm{Sn}+1$ at. $\% \mathrm{Ni}$ substrate is discussed in details in [21].

The appearance of $\mathrm{Ni}_{3} \mathrm{Sn}_{4}$ phase results directly from the Sn-Ni binary phase diagram [22]. The SEM/ EDS analysis showed some fluctuations of the copper concentration in the $\left(\mathrm{Ni}_{1-\mathrm{x}} \mathrm{Cu}_{\mathrm{x}}\right)_{3} \mathrm{Sn}_{4}$ phase depending on its distance from the $\mathrm{Cu}$ and $(\mathrm{Sn}+1 \mathrm{at} . \% \mathrm{Ni})$ reaction zone. The grains located far from the interface contained on average: $3.1 \pm 0.4$ at. $\%$ of $\mathrm{Cu}, 39.4 \pm 0.8$ at.\% of $\mathrm{Ni}, 57.5 \pm 1.2$ at.\% of $\mathrm{Sn}$ and those located closer: $6.1 \pm 1.0$ at. $\%$ of $\mathrm{Cu}, 33.6 \pm 1.3$ at. $\%$ of $\mathrm{Ni}$, $60.3 \pm 1.2$ at. $\%$ of $\mathrm{Sn}$.

Apart from the $\left(\mathrm{Ni}_{1-x} \mathrm{Cu}_{\mathrm{x}}\right)_{3} \mathrm{Sn}_{4}$ phase, the growth of two additional new intermetallic phases was observed, which were identified as $\left(\mathrm{Cu}_{1-\mathrm{x}} \mathrm{Ni}_{\mathrm{x}}\right)_{6} \mathrm{Sn}_{5}$ and $\mathrm{Cu}_{3} \mathrm{Sn}$. The $\left(\mathrm{Cu}_{1-x} \mathrm{Ni}_{x}\right)_{6} \mathrm{Sn}_{5}$ phase formed with a dual morphology. From the $(\mathrm{Sn}+1 \mathrm{at} \% \mathrm{Ni})$ pad side, the grains of irregular shapes surrounded by the pure

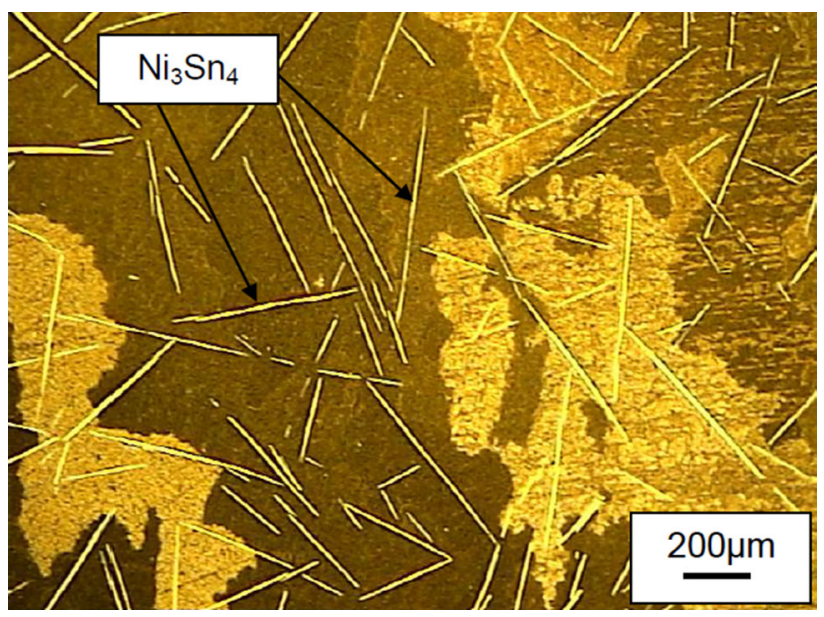

Figure 2 Etched surface of the $(\mathrm{Sn}+1 \mathrm{at} . \% \mathrm{Ni})$ substrate with visible needle precipitates of the randomly and evenly distributed in the Sn matrix (optical microscope).
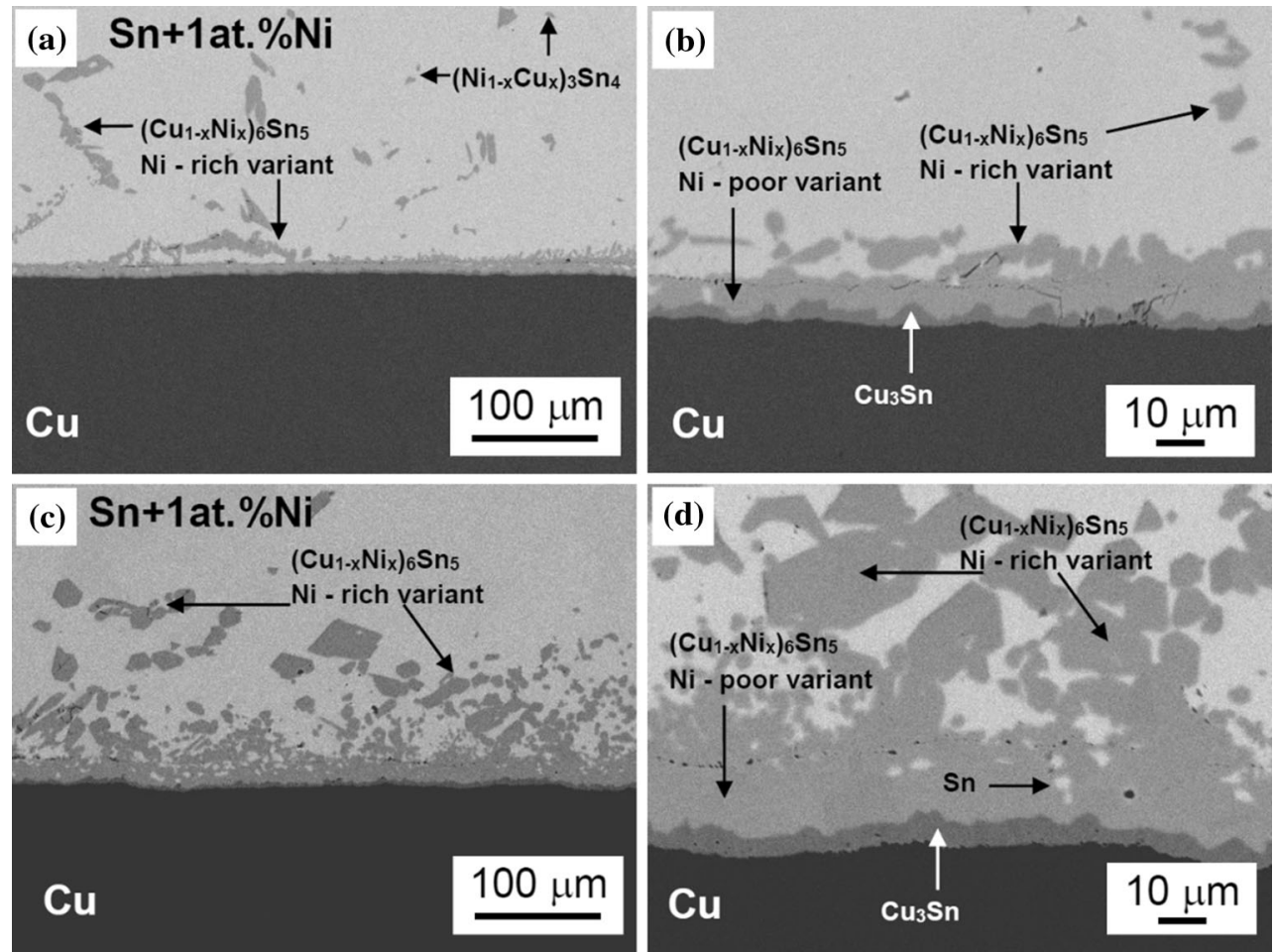

Figure 1 SEM images of $\mathrm{Cu} /\left(\mathrm{Sn}+1\right.$ at.\%Ni) diffusion couples obtained at $220{ }^{\circ} \mathrm{C}$ for $\mathbf{a}, \mathbf{b} 48 \mathrm{~h}$ and $\mathbf{c}, \mathbf{d} 225 \mathrm{~h}$. 
tin were observed, whereas the discontinuous layer of $\left(\mathrm{Cu}_{1-x} \mathrm{Ni}_{\mathrm{x}}\right)_{6} \mathrm{Sn}_{5}$ appeared closer to the center of the diffusion couple (Fig. 1). The EDS/SEM quantitative analysis clearly showed that dual morphology was accompanied by the fluctuation of the chemical composition of the $\left(\mathrm{Cu}_{1-x} \mathrm{Ni}_{x}\right)_{6} \mathrm{Sn}_{5}$ phase. The layer of $\left(\mathrm{Cu}_{1-\mathrm{x}} \mathrm{Ni}_{\mathrm{x}}\right)_{6} \mathrm{Sn}$ consisted of $48.5 \pm 0.9$ at. $\% \mathrm{Cu}$, $5.3 \pm 0.3$ at. $\% \mathrm{Ni}$ and $46.2 \pm 0.9$ at. $\%$ Sn (called in the text as "Ni-poor"), while the large grains contained $35.0 \pm 0.7$ at. $\% \mathrm{Cu}, 19.2 \pm 0.8$ at. $\% \mathrm{Ni}$ and $45.8 \pm 0.9$ at.\% Sn (referred to as "Ni-rich"). The differences in the morphology, chemical composition and localization of the $\left(\mathrm{Cu}_{1-x} \mathrm{Ni}_{\mathrm{x}}\right)_{6} \mathrm{Sn}_{5}$ phase were attributed to various mechanisms of its formation. The Ni-rich variant transformed from the $\mathrm{Ni}_{3} \mathrm{Sn}_{4}$ phase present in the initial $(\mathrm{Sn}, \mathrm{Ni})$ end member. On the other hand, the formation of the Ni-poor layer took place as a result of diffusion at the initial interface. The detailed description and explanation of the phenomena were presented in previous papers [21, 23]. The third phase, generated during annealing close to the copper substrate in the form of a continuous layer, was identified as $\mathrm{Cu}_{3} \mathrm{Sn}(74.5 \pm 1.5$ at.\% of $\mathrm{Cu}, 0.2 \pm 0.1$ at.\% of $\mathrm{Ni}$ and $25.3 \pm 0.5$ at.\% of $\mathrm{Sn}$ ) [21]. Such a complex microstructure of the reaction zone obtained in the $\mathrm{Cu} /(\mathrm{Sn}, \mathrm{Ni})$ diffusion couples with 1 and 3 at.\% of the nickel addition annealed at 160, 180 and $200{ }^{\circ} \mathrm{C}$ for various times up to $1139.5 \mathrm{~h}$ was also described by Nakayama et al. [24]. However, in comparison with the presented results, some differences in the chemical composition of the formed phases were found. Nakayama et al. [24] observed three intermetallic phases. The thin continuous layer of $\mathrm{Cu}_{3} \mathrm{Sn}$ phase was established close to the $\mathrm{Cu}$ pad. The next layer was identified as the $\mathrm{Cu}_{6} \mathrm{Sn}_{5}$ phase, without the nickel content. The Ni was detected only in single detached grains in the form of $(\mathrm{Cu}, \mathrm{Ni})_{6} \mathrm{Sn}_{5}$. The authors suggested that the different mechanisms of the $\mathrm{Cu}_{6} \mathrm{Sn}_{5}$ phase formation were the reason for the occurrence of dual morphology phenomena and fluctuations of the Ni concentration [24].

\section{Growth kinetics of the intermetallic phases}

The thickness of the Ni-poor $\left(\mathrm{Cu}_{1-\mathrm{x}} \mathrm{Ni}_{\mathrm{x}}\right)_{6} \mathrm{Sn}_{5}$ and $\mathrm{Cu}_{3} \mathrm{Sn}$ phases was measured using the R-tools program based on the series of SEM micrographs [19].

The experimental results of the measured average thicknesses of $\mathrm{Cu}_{3} \mathrm{Sn}$ and Ni-poor $\left(\mathrm{Cu}_{1-x} \mathrm{Ni}_{x}\right)_{6} \mathrm{Sn}_{5}$ layers for different annealing times at temperatures 200, 215 and $220{ }^{\circ} \mathrm{C}$ are presented in Table 1 and Table 2.

The thickness of the growing phase/layer $(\Lambda)$ can be expressed as function of time $(t)$

$\Lambda=k t^{n}$

where the value of the power $n$ determines the mechanism controlling the kinetics of layer growth. For example, $n=0.5$ means that the process is controlled by volume diffusion. Measured thicknesses of the layers $\mathrm{Cu}_{3} \mathrm{Sn}$ and Ni-poor $\left(\mathrm{Cu}_{1-x} \mathrm{Ni}_{\mathrm{x}}\right)_{6} \mathrm{Sn}_{5}$ as function of time are presented in Figs. 3 and 4. The values of $n$ for the $\mathrm{Cu}_{3} \mathrm{Sn}$ phase at temperatures 200,
Table 1 Measured average thicknesses $(\Lambda)$ of $\mathrm{Cu}_{3} \mathrm{Sn}$ layer and their standard deviation error $(\sigma)$ for different annealing times at temperatures 200,215 and $220{ }^{\circ} \mathrm{C}$

Table 2 Measured average thicknesses $(\Lambda)$ of $\left(\mathrm{Cu}_{1-\mathrm{x}} \mathrm{Ni}_{\mathrm{x}}\right)_{6} \mathrm{Sn} \mathrm{Ni}$-poor layer and their standard deviation error $(\sigma)$ for different annealing times at 200, 215 and $220{ }^{\circ} \mathrm{C}$

\begin{tabular}{|c|c|c|c|c|c|c|}
\hline \multirow[t]{2}{*}{ Time } & \multicolumn{2}{|l|}{$200{ }^{\circ} \mathrm{C}$} & \multicolumn{2}{|l|}{$215^{\circ} \mathrm{C}$} & \multicolumn{2}{|l|}{$220^{\circ} \mathrm{C}$} \\
\hline & $\Lambda, \mu \mathrm{m}$ & $\sigma, \mu \mathrm{m}$ & $\Lambda, \mu \mathrm{m}$ & $\sigma, \mu \mathrm{m}$ & $\Lambda, \mu \mathrm{m}$ & $\sigma, \mu \mathrm{m}$ \\
\hline 2 days (48 h) & 1.48 & 0.39 & 1.8 & 0.44 & 2.16 & 0.92 \\
\hline 5 days $(120 \mathrm{~h})$ & 2.17 & 0.71 & 2.73 & 0.61 & 3.63 & 1.22 \\
\hline 7 days (168 h) & 2.3 & 0.59 & 3.35 & 1.01 & 3.82 & 0.86 \\
\hline 9.3 days $(225 \mathrm{~h})$ & 3.17 & 0.94 & 3.83 & 1.14 & - & - \\
\hline
\end{tabular}

\begin{tabular}{|c|c|c|c|c|c|c|}
\hline \multirow[t]{2}{*}{ Time } & \multicolumn{2}{|l|}{$200{ }^{\circ} \mathrm{C}$} & \multicolumn{2}{|l|}{$215^{\circ} \mathrm{C}$} & \multicolumn{2}{|l|}{$220{ }^{\circ} \mathrm{C}$} \\
\hline & $\Lambda, \mu \mathrm{m}$ & $\sigma, \mu \mathrm{m}$ & $\Lambda, \mu \mathrm{m}$ & $\sigma, \mu \mathrm{m}$ & $\Lambda, \mu \mathrm{m}$ & $\sigma, \mu \mathrm{m}$ \\
\hline 2 days $(48 \mathrm{~h})$ & 4.30 & 1.44 & 5.82 & 1.22 & 6.75 & 1.65 \\
\hline 5 days $(120 \mathrm{~h})$ & 6.43 & 2.23 & 8.27 & 1.72 & 10.69 & 2.05 \\
\hline 7 days $(168 \mathrm{~h})$ & 8.03 & 1.41 & 10.57 & 2.08 & 11.63 & 2.95 \\
\hline 9.3 days $(225 \mathrm{~h})$ & 9.11 & 2.82 & 10.92 & 1.97 & - & - \\
\hline
\end{tabular}




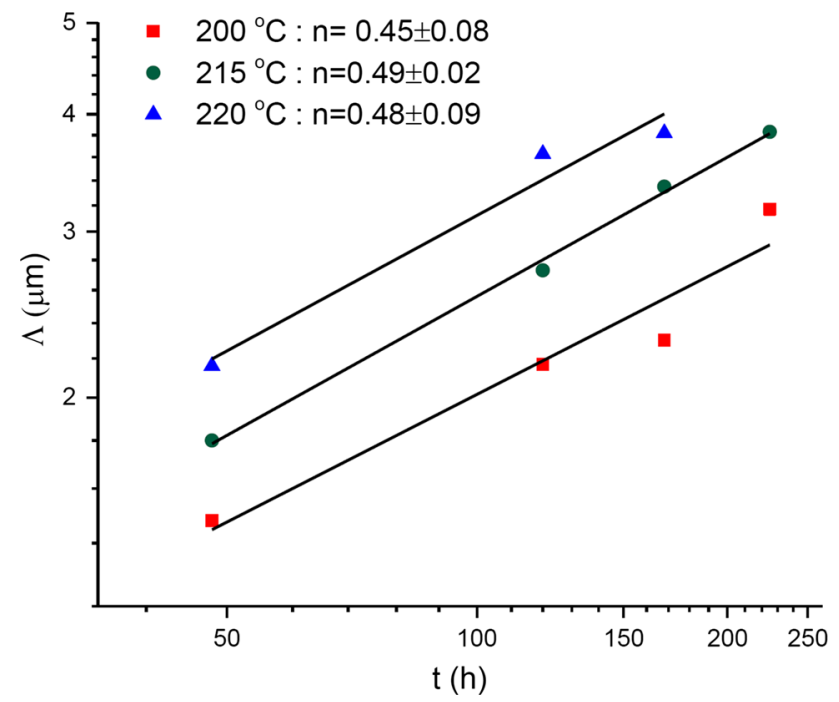

Figure 3 Thickness of $\mathrm{Cu}_{3} \mathrm{Sn}$ layer as function of time (logarithmic scale) for temperatures 200,215 and $220{ }^{\circ} \mathrm{C}$.

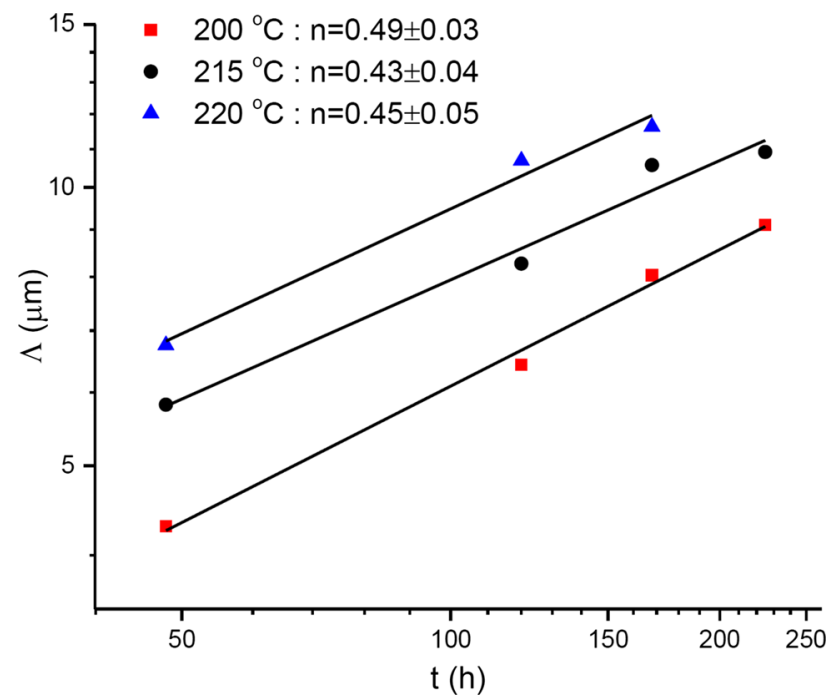

Figure 4 Thickness of Ni-poor $\left(\mathrm{Cu}_{1-\mathrm{x}} \mathrm{Ni}_{\mathrm{x}}\right)_{6} \mathrm{Sn}_{5} \mathrm{Cu}_{3} \mathrm{Sn}$ layer as function of time (logarithmic scale) for temperatures 200, 215 and $220{ }^{\circ} \mathrm{C}$.

215 and $220^{\circ} \mathrm{C}$ calculated by the least square linear approximation method are $0.45 \pm 0.08,0.49 \pm 0.02$ and $0.48 \pm 0.09$. They indicate that the growth of $\mathrm{Cu}_{3} \mathrm{Sn}$ layer is controlled by volume diffusion for all studied temperatures.

The calculated values of $n$ determined for $\mathrm{Ni}$-poor $\left(\mathrm{Cu}_{1-\mathrm{x}} \mathrm{Ni}_{\mathrm{x}}\right)_{6} \mathrm{Sn}_{5}$ layer were $0.49 \pm 0.03,0.43 \pm 0.04$ and $0.45 \pm 0.05$ for temperatures 200,215 and $220{ }^{\circ} \mathrm{C}$, respectively. Those data indicated that volume diffusion was a dominating growth mechanism at all temperatures.
Such a similar parabolic growth mechanism was reported by Tang et al. [25] and Yuan et al. [26] for the $\mathrm{Cu}_{3} \mathrm{Sn}$ and $\mathrm{Cu}_{6} \mathrm{Sn}_{5}$ phases formed in the $\mathrm{Cu} / \mathrm{Sn}$ diffusion couples. Their results suggested that nickel addition to the Sn substrate did not influence the character of phases growth as significantly as the morphology.

In the case of the Ni-rich $\left(\mathrm{Cu}_{1-x} \mathrm{Ni}_{\mathrm{x}}\right)_{6} \mathrm{Sn}_{5}$ phase, the situation was even more complicated than it was mentioned above. The description of the phase growth which has a complex three-dimensional geometry may be expressed by the volume of Ni-rich $\left(\mathrm{Cu}_{1-x} \mathrm{Ni}_{\mathrm{x}}\right)_{6} \mathrm{Sn}_{5}$ phase in function of time. Unfortunately, only two-dimensional sections of these grains could be obtained from the experiments that had been carried out in the study. However, under some assumptions, useful information about the three-dimensional growth could be deduced from the twodimensional measurements.

The total volume of grains is given by integral $|V|=\int_{0}^{H}\left|V_{h}\right| d h$, where $V_{h}$ is the cross section of a set $V$ at height $h$. Hence, $V$ represents the grain phase and | | denotes the volume or area of a given set (3D or 2D measure). Assuming that a distribution of grains is uniform, the approximation $\left|V_{h}\right| \approx A_{0}$ can be used; hence, $|V|=A_{0} H$, where $A_{0}$ is the area of grains in any representative cross section. Thus

$\% V=|V| /\left|V_{\text {total }}\right|=A_{0} H / A_{\text {total }} H=A_{0} / A_{\text {total }}$.

In practice $A_{0}$ is the average of several measurements along the phase boundary for one cross section. Such possibility results from the fact that probabilities of grain distribution in "vertical" and "horizontal" directions are assumed to be equal. This is a very important property because it allows omitting the necessity to cut out many cross sections $V_{h}$ for different $h$.

Thus, provided that the distribution is uniform and relatively dense, the kinetics of volume growth can be obtained by $2 \mathrm{D}$ measurements.

The question of the mechanism of kinetic growth (reaction or diffusion control) can be answered by the following reasoning. It can be shown that for simple shapes (spheres, cubes, ellipsoids), the linear dimension of growing grain is proportional to $\sqrt{t}$ if the process is diffusion controlled; hence, the area is proportional to $t$. More complicated shapes can locally be viewed as similar to plane or sphere, so we 


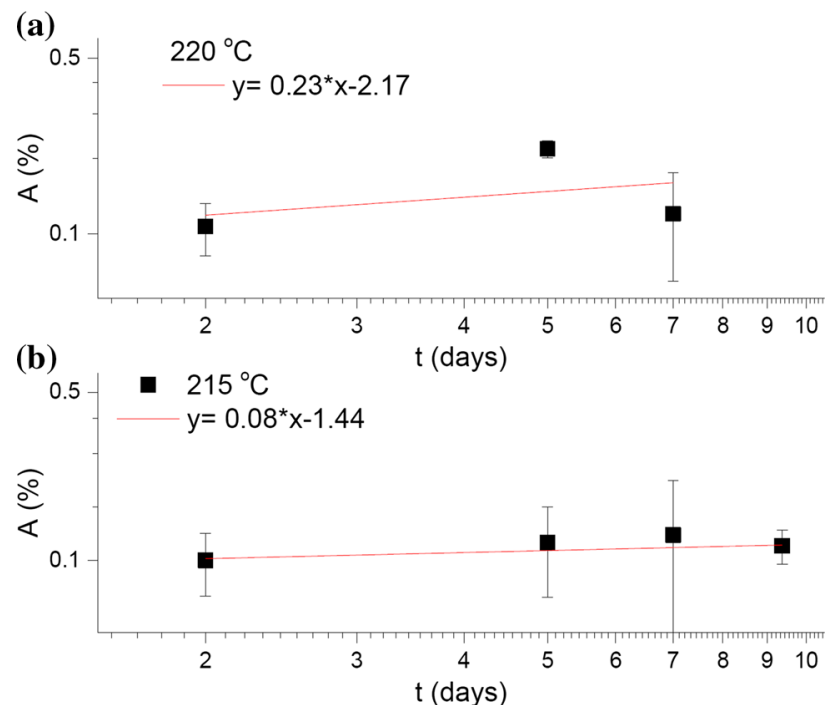

Figure 5 Ratio of area of grains to the total area at the cross section as function of time for Ni-rich $\left(\mathrm{Cu}_{1-\mathrm{x}} \mathrm{Ni}_{\mathrm{x}}\right)_{6} \mathrm{Sn}_{5}$ at: a $220{ }^{\circ} \mathrm{C}$ and $\mathbf{b} 215^{\circ} \mathrm{C}$.

can extrapolate this criterion to the general case. Thus, if the $2 \mathrm{D}$ area of grains fraction is proportional to $t$, i.e., $\% A(t) \sim t$, the kinetics is diffusion controlled.

The changes of the Ni-rich $\left(\mathrm{Cu}_{1-x} \mathrm{Ni}_{\mathrm{x}}\right)_{6} \mathrm{Sn}_{5}$ phase area with time in the bilogarithmic scale for temperatures 215 and $220^{\circ} \mathrm{C}$ are presented in Fig. 5.

\section{Mathematical model of layers growth}

Based on the results presented above, the mathematical model of intermetallic layer growth was proposed and the diffusion coefficients for the $\mathrm{Cu}_{3} \mathrm{Sn}$ and $\mathrm{Ni}$-poor $\left(\mathrm{Cu}_{1-x} \mathrm{Ni}_{x}\right)_{6} \mathrm{Sn}_{5}$ phases were determined. The diffusion coefficient calculations for the layer of Ni-rich variant require additional studies and will be the subject of further work because of the complex morphology of the $\left(\mathrm{Cu}_{1-x} \mathrm{Ni}_{\mathrm{x}}\right)_{6} \mathrm{Sn}$ phase. Figure 6 presents schematic graph of layer growth in $\mathrm{Cu} /$ $(\mathrm{Sn}+1$ at.\%Ni).

The model assumes that growth of layers is the result of the diffusion of $\mathrm{Cu}$ and $\mathrm{Sn}$ components in each layer:

$\frac{\partial c^{2}}{\partial t}(x, t)=-\frac{\partial J^{2}}{\partial x}(x, t) \quad$ for $s_{1}(t)<x<s_{2}(t)$,

$\frac{\partial c^{3}}{\partial t}(x, t)=-\frac{\partial J^{3}}{\partial x}(x, t) \quad$ for $s_{2}(t)<x<s_{3}(t)$,

where $c^{2}$ and $c^{3}$ and $J^{2}$ and $J^{3}$ are the concentrations and fluxes of $\mathrm{Cu}$ in the layers "2" and " 3 ," respectively, i.e., for layers $\mathrm{Cu}_{3} \mathrm{Sn}$ and $\left(\mathrm{Cu}_{1-x} \mathrm{Ni}_{\mathrm{x}}\right)_{6} \mathrm{Sn}_{5}$.

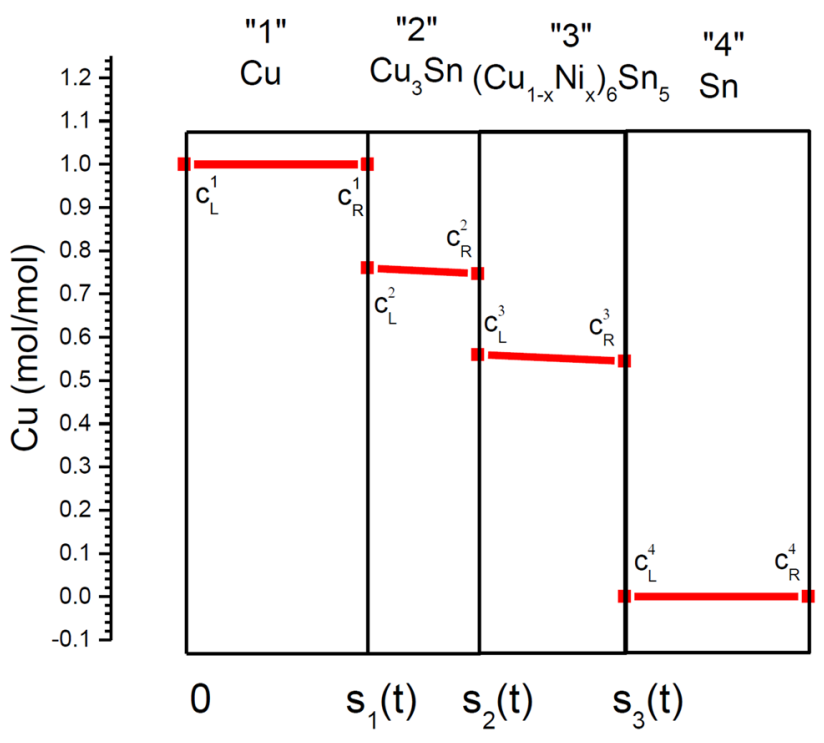

Figure 6 Schematic graph of $\mathrm{Cu}_{3} \mathrm{Sn}$ and $\left(\mathrm{Cu}_{1-\mathrm{x}} \mathrm{Ni}_{\mathrm{x}}\right)_{6} \mathrm{Sn}_{5}$ layer growth in $\mathrm{Cu} /(\mathrm{Sn}+1$ at.\%Ni) system.

The movement of the boundaries $\mathrm{Cu} / \mathrm{Cu}_{3} \mathrm{Sn}$, $\mathrm{Cu}_{3} \mathrm{Sn} /\left(\mathrm{Cu}_{1-x} \mathrm{Ni}_{\mathrm{x}}\right)_{6} \mathrm{Sn}_{5}$ and $\left(\mathrm{Cu}_{1-\mathrm{x}} \mathrm{Ni}_{\mathrm{x}}\right)_{6} \mathrm{Sn}_{5} / \mathrm{Sn}$ is described by mass balance equations at the moving boundaries $s_{1}(t), s_{2}(t)$ and $s_{3}(t)$, respectivelyso-called Stefan boundary conditions [27, 28]:

$$
\begin{aligned}
&\left(c_{R}^{1}-c_{L}^{2}\right) \frac{d s_{1}}{d t}(t)=J^{1}\left(s_{1}(t), t\right)-J^{2}\left(s_{1}(t), t\right), \\
&\left(c_{R}^{2}-c_{L}^{3}\right) \frac{d s_{2}}{d t}(t)=J^{2}\left(s_{2}(t), t\right)-J^{3}\left(s_{2}(t), t\right), \\
&\left(c_{R}^{3}-c_{L}^{4}\right) \frac{d s_{3}}{d t}(t)=J^{3}\left(s_{3}(t), t\right)-J^{4}\left(s_{3}(t), t\right), \\
& \text { for } t>0,
\end{aligned}
$$

where $c^{j}(x, t), J^{j}(x, t)$-concentration and flux of copper in the $j$-th layer at position $x$ and for the time $t$, $c_{L}^{j}, c_{R}^{j}$-concentrations of copper in the $j$-th layer on the left and right boundary, $s_{1}(t), s_{2}(t)$ and $s_{3}(t)-$ positions of the $\mathrm{Cu} / \mathrm{Cu}_{3} \mathrm{Sn}, \mathrm{Cu}_{3} \mathrm{Sn} /\left(\mathrm{Cu}_{1-x} \mathrm{Ni}_{\mathrm{x}}\right)_{6} \mathrm{Sn}_{5}$ and $\left(\mathrm{Cu}_{1-x} \mathrm{Ni}_{\mathrm{x}}\right)_{6} \mathrm{Sn}_{5} / \mathrm{Sn}$ boundaries at time $t$.

In the case of two component system, the flux of copper in the $j$-th layer can be expressed by Fick's formula [29]

$J^{j}=-\tilde{D}^{j} \frac{\partial c^{j}}{\partial x}$

where $\tilde{D}^{j}$ is the interdiffusion coefficient in the $j$-th layer [30]. For compounds of narrow homogeneity range (so-called line compounds), one can assume that the concentration profile is linear and consequently Eq. (4) can be expressed as follows 
$J^{j}=-\tilde{D}^{j} \frac{c_{R}^{j}-c_{L}^{j}}{s_{j}(t)-s_{j-1}(t)}$,

where $c_{L}^{j}, c_{R}^{j}$ are concentrations of copper in the $j$-th layer on its left and right boundary; $s_{j}(t)-s_{j-1}(t)$ is the thickness of $j$-th layer at time $t$.

Assuming negligible solubility of tin in copper in layer " 1 " and constant copper concentration in layer " 4 " it can be assumed:

$c_{R}^{1}=c_{L}^{1}, \quad J^{1}\left(s_{1}(t), t\right)=0$,

$c_{R}^{4}=c_{L}^{4}, \quad J^{3}\left(s_{3}(t), t\right)=0$.

Consequently, Eq. (3) takes the following form

$\left(c_{R}^{1}-c_{L}^{2}\right) \frac{d s_{1}}{d t}(t)=\tilde{D}^{2} \frac{c_{R}^{2}-c_{L}^{2}}{s_{2}(t)-s_{1}(t)}$,

$\left(c_{R}^{2}-c_{L}^{3}\right) \frac{d s_{2}}{d t}(t)=-\tilde{D}^{2} \frac{c_{R}^{2}-c_{L}^{2}}{s_{2}(t)-s_{1}(t)}+\tilde{D}^{3} \frac{c_{R}^{3}-c_{L}^{3}}{s_{3}(t)-s_{2}(t)}$,

$\left(c_{R}^{3}-c_{L}^{4}\right) \frac{d s_{3}}{d t}(t)=-\tilde{D}^{3} \frac{c_{R}^{3}-c_{L}^{3}}{s_{3}(t)-s_{2}(t)}$.

Introducing the notations:

$a_{1}:=c_{R}^{1}-c_{L}^{2}, \quad a_{2}:=c_{R}^{2}-c_{L}^{3}, \quad a_{3}:=c_{R}^{3}-c_{L}^{4}$,

$$
\Delta c_{2}:=c_{R}^{2}-c_{L}^{2}, \quad \Delta c_{3}:=c_{R}^{3}-c_{L}^{3},
$$

Equation (8) can be written as follows:

$a_{1} \frac{d s_{1}}{d t}(t)=\tilde{D}^{2} \frac{\Delta c_{2}}{s_{2}(t)-s_{1}(t)}$,

$a_{2} \frac{d s_{2}}{d t}(t)=-\tilde{D}^{2} \frac{\Delta c_{2}}{s_{2}(t)-s_{1}(t)}+\tilde{D}^{3} \frac{\Delta c_{3}}{s_{3}(t)-s_{2}(t)}$,

$a_{3} \frac{d s_{3}}{d t}(t)=-\tilde{D}^{3} \frac{\Delta c_{3}}{s_{3}(t)-s_{2}(t)}$.

From (10), the equations describing velocities of the boundaries can be obtained:

$\frac{d s_{1}}{d t}(t)=\tilde{D}^{2} \frac{\Delta c_{2}}{a_{1}} \frac{1}{s_{2}(t)-s_{1}(t)}$,

$\frac{d s_{2}}{d t}(t)=-\tilde{D}^{2} \frac{\Delta c_{2}}{a_{2}} \frac{1}{s_{2}(t)-s_{1}(t)}+\tilde{D}^{3} \frac{\Delta c_{3}}{a_{2}} \frac{1}{s_{3}(t)-s_{2}(t)}$,

$\frac{d s_{3}}{d t}(t)=-\tilde{D}^{3} \frac{\Delta c_{3}}{a_{3}} \frac{1}{s_{3}(t)-s_{2}(t)}$.

Subtracting Eqs. (11):

$$
\begin{aligned}
& \frac{d}{d t}\left(s_{2}(t)-s_{1}(t)\right)=-\tilde{D}^{2} \Delta c_{2}\left(\frac{1}{a_{2}}+\frac{1}{a_{1}}\right) \frac{1}{s_{2}(t)-s_{1}(t)} \\
& \quad+\frac{\tilde{D}^{3} \Delta c_{3}}{a_{2}} \frac{1}{s_{3}(t)-s_{2}(t)}, \\
& \frac{d}{d t}\left(s_{3}(t)-s_{2}(t)\right)=\frac{\tilde{D}^{2} \Delta c_{2}}{a_{2}} \frac{1}{s_{2}(t)-s_{1}(t)} \\
& \quad-\tilde{D}^{3} \Delta c_{3}\left(\frac{1}{a_{3}}+\frac{1}{a_{2}}\right) \frac{1}{s_{3}(t)-s_{2}(t)},
\end{aligned}
$$

and introducing further notations:

$$
\begin{aligned}
& X(t):=s_{2}(t)-s_{1}(t), \quad Y(t):=s_{3}(t)-s_{2}(t), \\
& B_{11}=\frac{\tilde{D}^{3} \Delta c_{3}}{a_{2}}, \quad B_{12}:=-\tilde{D}^{2} \Delta c_{2}\left(\frac{1}{a_{2}}+\frac{1}{a_{1}}\right), \\
& B_{21}:=-\tilde{D}^{3} \Delta c_{3}\left(\frac{1}{a_{3}}+\frac{1}{a_{2}}\right), \quad B_{22}:=\frac{\tilde{D}^{2} \Delta c_{2}}{a_{2}},
\end{aligned}
$$

Equation (12) takes the form:

$$
\begin{aligned}
& \frac{d}{d t} X(t)=\frac{B_{11}}{Y(t)}+\frac{B_{12}}{X(t)}, \\
& \frac{d}{d t} Y(t)=\frac{B_{21}}{Y(t)}+\frac{B_{22}}{X(t)} .
\end{aligned}
$$

Equation (14) with the initial condition-i.e., thicknesses of layers $X, Y$ at time zero, defines the following Cauchy problem [31] for a system of two ordinary differential equations (ODEs):

$$
\left\{\begin{array}{l}
\frac{d}{d t} X(t)=\frac{B_{11}}{Y(t)}+\frac{B_{12}}{X(t)}, \quad \frac{d}{d t} Y(t)=\frac{B_{21}}{Y(t)}+\frac{B_{22}}{X(t)}, \\
X(0)=X_{0}, \quad Y(0)=Y_{0} .
\end{array}\right.
$$

Solving numerically problem (15) gives layer thicknesses $X(t)$ and $Y(t)$ as function of time.

\section{Determination of diffusion coefficients for the layers of $\mathrm{Cu}_{3} \mathrm{Sn}$ and Ni-poor $\left(\mathrm{Cu}_{1-x} \mathrm{Ni}_{\mathrm{x}}\right)_{6} \mathrm{Sn}_{5}$ phases}

A numerical solution of problem (15) is a function of (unknown) interdiffusion coefficients, $\tilde{D}^{2}, \tilde{D}^{3}$ in layers "2" and "3," respectively: 


$$
\begin{aligned}
& X(t)=X\left(t, \tilde{D}^{2}, \tilde{D}^{3}\right), \\
& Y(t)=Y\left(t, \tilde{D}^{2}, \tilde{D}^{3}\right) .
\end{aligned}
$$

These diffusion coefficients can be determined by solution of the suitable inverse problem, but additional information is necessary, in this case, the measured layer thicknesses at several times. Denoting as:

$$
\begin{gathered}
X^{\exp }\left(t_{1}\right), \ldots, X^{\exp }\left(t_{N}\right), \\
Y^{\exp }\left(t_{1}\right), \ldots, Y^{\exp }\left(t_{N}\right),
\end{gathered}
$$

the measured thicknesses of layers $\mathrm{Cu}_{3} \mathrm{Sn}$ and $\mathrm{Ni}$ poor $\left(\mathrm{Cu}_{1-x} \mathrm{Ni}_{\mathrm{x}}\right)_{6} \mathrm{Sn}_{5}$ at times $t_{1}, \ldots, t_{N}$, the following function can be defined:

$$
\begin{aligned}
\operatorname{GoalF}\left(\tilde{D}^{2}, \tilde{D}^{3}\right)= & \sum_{k=1}^{N}\left(X\left(t_{k}, \tilde{D}^{2}, \tilde{D}^{3}\right)-X^{\exp }\left(t_{k}\right)\right)^{2} \\
& +\sum_{k=1}^{N}\left(Y\left(t_{k}, \tilde{D}^{2}, \tilde{D}^{3}\right)-Y^{\exp }\left(t_{k}\right)\right)^{2},
\end{aligned}
$$

which is a "distance" between measured and calculated (from the model) thicknesses of layers " 2 " and " 3 " at times $t_{1}, \ldots, t_{N}$.

In order to determine diffusion coefficients, function (18) has to be minimized and values of $\tilde{D}^{2}, \tilde{D}^{3}$ which minimize goal function (18) are looked for:

$$
\text { GoalF } \rightarrow \min _{\tilde{D}^{2}, \tilde{D}^{3}} \operatorname{GoalF}\left(\tilde{D}^{2}, \tilde{D}^{3}\right) \text {. }
$$

The calculations for the system $\mathrm{Cu} /(\mathrm{Sn}+1 \mathrm{at} . \% \mathrm{Ni})$ were performed for temperatures 200,215 and $220{ }^{\circ} \mathrm{C}$ using the following data (see notations in Fig. 6):

1. $c_{L}^{1}=c_{R}^{1}=1 \mathrm{~mol} / \mathrm{mol}$

2. $c_{L}^{2}=0.76 \mathrm{~mol} / \mathrm{mol}$

3. $c_{R}^{2}=0.747 \mathrm{~mol} / \mathrm{mol}$

4. $c_{L}^{3}=0.56 \mathrm{~mol} / \mathrm{mol}$

5. $c_{L}^{3}=0.545 \mathrm{~mol} / \mathrm{mol}$

6. $c_{L}^{4}=c_{R}^{4}=0 \mathrm{~mol} / \mathrm{mol}$

7. $X(0)=1 \cdot 10^{-9} \mathrm{~m}, \quad Y(0)=1 \cdot 10^{-9} \mathrm{~m}$

Based on the formulated above inverse problem (18)-(19), the diffusion coefficients for layers $\mathrm{Cu}_{3} \mathrm{Sn}$ and $\mathrm{Ni}$-poor $\left(\mathrm{Cu}_{1-x} \mathrm{Ni}_{x}\right)_{6} \mathrm{Sn}_{5}$ for the system $\mathrm{Cu} /$ $(\mathrm{Sn}+1 \mathrm{at} . \% \mathrm{Ni})$ and temperatures 200,215 and $220{ }^{\circ} \mathrm{C}$ were calculated and are presented in Table 3.

Figures 7, 8 and 9 show comparison of calculated evolution of layer thickness (for diffusion coefficients
Table 3 Diffusion coefficients calculated using the inverse problem for layers $\mathrm{Cu}_{3} \mathrm{Sn}$ and Ni-poor $\left(\mathrm{Cu}_{1-\mathrm{x}} \mathrm{Ni}_{\mathrm{x}}\right)_{6} \mathrm{Sn}_{5}$ for $\mathrm{Cu} /$ $(\mathrm{Sn}+1$ at.\%Ni) diffusion couples for selected temperatures

\begin{tabular}{lll}
\hline$T\left({ }^{\circ} \mathrm{C}\right)$ & $\tilde{\mathrm{D}}_{\mathrm{Cu}_{3} \mathrm{Sn}}, \mathrm{m}^{2} \mathrm{~s}^{-1}$ & $\tilde{\mathrm{D}}_{(\mathrm{Cu}, \mathrm{Ni})_{6} S n_{5}}, \mathrm{~m}^{2} \mathrm{~s}^{-1}$ \\
\hline 200 & $2.48 \times 10^{-16}$ & $9.71 \times 10^{-16}$ \\
215 & $3.95 \times 10^{-16}$ & $14.46 \times 10^{-16}$ \\
220 & $5.99 \times 10^{-16}$ & $22.91 \times 10^{-16}$ \\
\hline
\end{tabular}

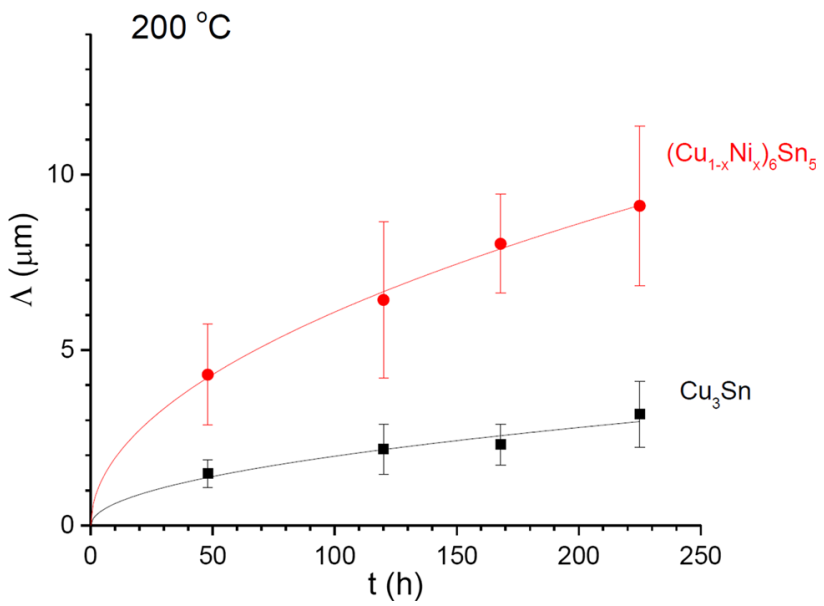

Figure 7 Calculated layer thicknesses (for diffusion coefficients from Table 3)-lines and experimentally measured average thicknesses of $\mathrm{Cu}_{3} \mathrm{Sn}$ and Ni-poor $\left(\mathrm{Cu}_{1-\mathrm{x}} \mathrm{Ni}_{\mathrm{x}}\right)_{6} \mathrm{Sn}_{5}$ layers (dots) for selected times for temperature $200{ }^{\circ} \mathrm{C}$.

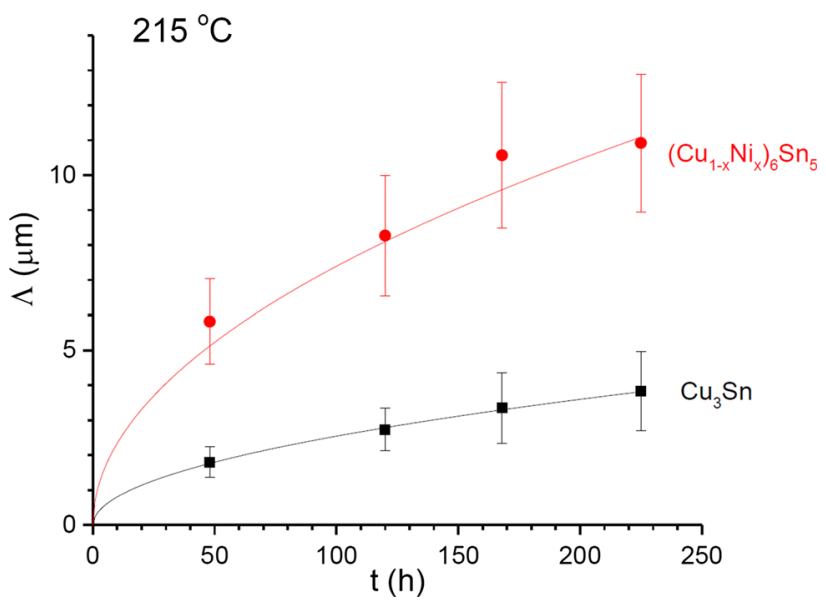

Figure 8 Calculated layer thicknesses (for diffusion coefficients from Table 3)-lines and experimentally measured average thicknesses of $\mathrm{Cu}_{3} \mathrm{Sn}$ and Ni-poor $\left(\mathrm{Cu}_{1-\mathrm{x}} \mathrm{Ni}_{\mathrm{x}}\right)_{6} \mathrm{Sn}_{5}$ layers (dots) for selected times for temperature $215^{\circ} \mathrm{C}$. 


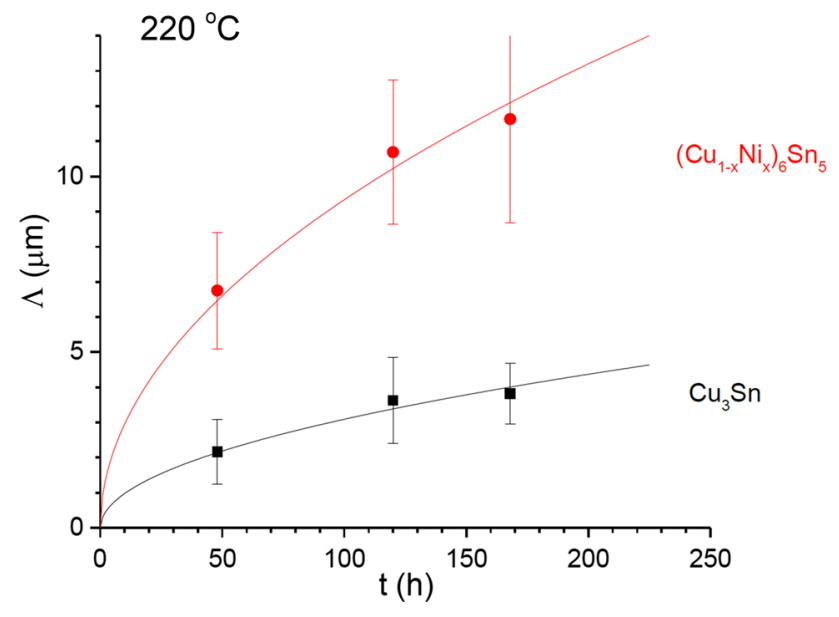

Figure 9 Calculated layer thicknesses (for diffusion coefficients from Table 3)-(lines) and experimentally measured average thicknesses of $\mathrm{Cu}_{3} \mathrm{Sn}$ and Ni-poor $\left(\mathrm{Cu}_{1-\mathrm{x}} \mathrm{Ni}_{\mathrm{x}}\right)_{6} \mathrm{Sn}_{5}$ layers (dots) for selected times for temperature $220{ }^{\circ} \mathrm{C}$.

from Table 3) with experimentally measured average thicknesses of $\mathrm{Cu}_{3} \mathrm{Sn}$ and Ni-poor $\left(\mathrm{Cu}_{1-x} \mathrm{Ni}_{x}\right)_{6} \mathrm{Sn}_{5}$ layers for various annealing times at 200, 215 and $220{ }^{\circ} \mathrm{C}$. As it can been seen, a very good agreement was achieved.

The calculated diffusion coefficients (solution of the inverse problem for $\mathrm{Cu} /(\mathrm{Sn}+1 \mathrm{at} . \% \mathrm{Ni})$ diffusion couples) for layers $\mathrm{Cu}_{3} \mathrm{Sn}$ and $\mathrm{Ni}$-poor $\left(\mathrm{Cu}_{1-x} \mathrm{Ni}_{\mathrm{x}}\right)_{6}$ $\mathrm{Sn}_{5}$ are compared in Tables 4 and 5 with literature data accessible for the $\mathrm{Cu} / \mathrm{Sn}$ system.

In both cases of $\mathrm{Cu}_{3} \mathrm{Sn}$ and Ni-poor $\left(\mathrm{Cu}_{1-x} \mathrm{Ni}_{x}\right)_{6} \mathrm{Sn}_{5}$ phases, a good agreement with literature data was obtained. The results confirm, once again, that in general the addition of the nickel into the tin does not

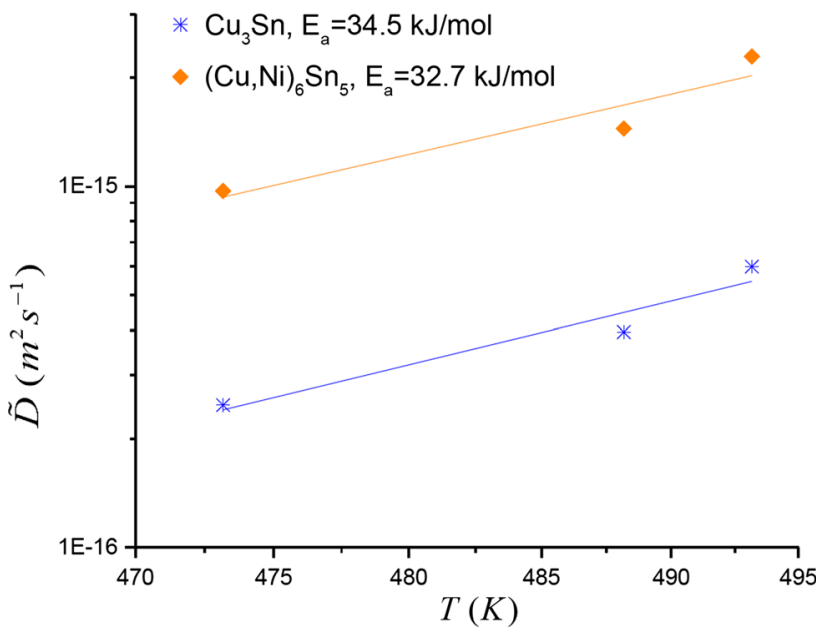

Figure 10 Interdiffusion coefficients for $\mathrm{Cu}_{3} \mathrm{Sn}$ and $\mathrm{Ni}$-poor $\left(\mathrm{Cu}_{1-\mathrm{x}} \mathrm{Ni}_{\mathrm{x}}\right)_{6} \mathrm{Sn}_{5}$ layers as function of temperature-Arrhenius plot obtained for $\mathrm{Cu} /(\mathrm{Sn}+1$ at.\%Ni) system.

affect significantly the diffusion processes associated with $\mathrm{Cu}_{3} \mathrm{Sn}$ and $\mathrm{Ni}$-poor $\left(\mathrm{Cu}_{1-x} \mathrm{Ni}_{\mathrm{x}}\right)_{6} \mathrm{Sn}_{5}$ phases in comparison with $\mathrm{Cu}_{3} \mathrm{Sn}$ and $\mathrm{Cu}_{6} \mathrm{Sn}_{5}$ formed in the binary $\mathrm{Cu} / \mathrm{Sn}$ system.

The interdiffusion coefficients for layers $\mathrm{Cu}_{3} \mathrm{Sn}$ and Ni-poor $\left(\mathrm{Cu}_{1-x} \mathrm{Ni}_{x}\right)_{6} \mathrm{Sn}_{5}$ for $\mathrm{Cu} /(\mathrm{Sn}+1$ at. $\% \mathrm{Ni})$ diffusion couples as function of temperature in the Arrhenius plot are presented in Fig. 10.

The activation energies for the layers $\mathrm{Cu}_{3} \mathrm{Sn}$ and $\mathrm{Ni}$-poor $\left(\mathrm{Cu}_{1-x} \mathrm{Ni}_{\mathrm{x}}\right)_{6} \mathrm{Sn}_{5}$ were determined to be $34 \pm 9$ and $33 \pm 11 \mathrm{~kJ} \mathrm{~mol}^{-1}$ using the standard least square linear approximation. However, significant discrepancies of activation energies for $\mathrm{Cu}_{3} \mathrm{Sn}$ and $\mathrm{Cu}_{6} \mathrm{Sn}_{5}$ layers in the binary $\mathrm{Cu} / \mathrm{Sn}$ system were found in the literature.
Table 4 Comparison of calculated diffusion coefficients for the $\mathrm{Cu}_{3} \mathrm{Sn}$ layer for different temperatures with literature data

\begin{tabular}{lllll}
\hline$T\left({ }^{\circ} \mathrm{C}\right)$ & $\tilde{\mathrm{D}}_{\mathrm{Cu}_{3} \mathrm{Sn}}, \mathrm{m}^{2} \mathrm{~s}^{-1}$ & & & \\
\cline { 2 - 5 } & Onishi and Fujibuchi [32] & Paul et al. [33] & Kumar et al. [34] & This work \\
\hline 200 & $2.22 \times 10^{-16}$ & $14.9 \times 10^{-16}$ & $1.92 \times 10^{-16}$ & $2.48 \times 10^{-16}$ \\
215 & $3.87 \times 10^{-16}$ & - & - & $3.95 \times 10^{-16}$ \\
220 & $4.62 \times 10^{-16}$ & - & - & $5.99 \times 10^{-16}$ \\
\hline
\end{tabular}

\begin{tabular}{lllll}
\hline$T\left({ }^{\circ} \mathrm{C}\right)$ & $\tilde{\mathrm{D}}_{\left(\mathrm{Cu}_{1-x} \mathrm{Ni}_{i}\right)_{6} \mathrm{Sn}_{5}, \mathrm{~m}^{2} \mathrm{~s}^{-1}}$ & & & \\
\cline { 2 - 5 } & Onishi and Fujibuchi [32] & Paul et al. [33] & Kumar et al. [34] & This work \\
\hline 200 & $10.88 \times 10^{-16}$ & - & $12.1 \times 10^{-16}$ & $9.71 \times 10^{-16}$ \\
215 & $18.04 \cdot 10^{-16}$ & - & - & $14.30 \times 10^{-16}$ \\
220 & $21.21 \times 10^{-16}$ & $37.6 \times 10^{-16}\left(225^{\circ} \mathrm{C}\right)$ & - & $22.91 \times 10^{-16}$ \\
\hline
\end{tabular}

Table 5 Comparison of calculated diffusion coefficients for the Ni-poor $\left(\mathrm{Cu}_{1-\mathrm{x}} \mathrm{Ni}_{\mathrm{x}}\right)_{6} \mathrm{Sn}_{5}$ layer for different temperatures with literature data 


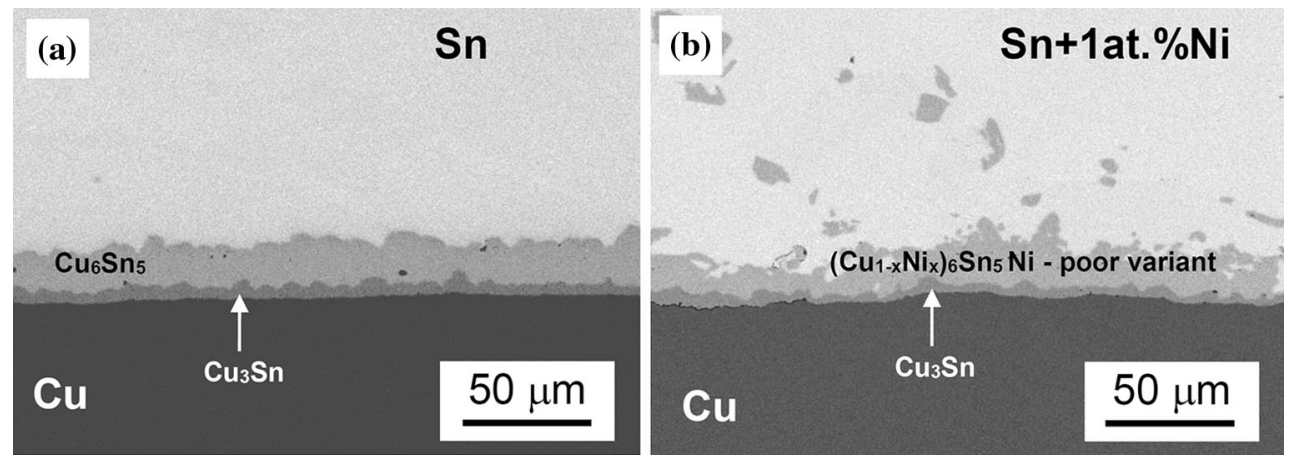

Figure 11 Comparison of the intermetallic phase thicknesses in: $\mathbf{a} \mathrm{Cu} / \mathrm{Sn}$ and $\mathbf{b ~ C u} /(\mathrm{Sn}+1 \mathrm{at} . \% \mathrm{Ni})$ diffusion couples obtained at $220{ }^{\circ} \mathrm{C}$ after $120 \mathrm{~h}$.

The presented results are in good agreement with those obtained by Onishi and Fujibuchi [32], in whose works the activation energy was $36.4 \mathrm{~kJ} \mathrm{~mol}^{-1}$ for $\mathrm{Cu}_{3} \mathrm{Sn}$ and $46.0 \mathrm{~kJ} \mathrm{~mol}^{-1}$ for $\mathrm{Cu}_{6} \mathrm{Sn}_{5}$ and those obtained by Kumar et al. [34] who reported $38.7 \pm 7.5$ and $47.3 \pm 5.2 \mathrm{~kJ} \mathrm{~mol}^{-1}$, respectively. Quite different values of activation energies of interdiffusion for $\mathrm{Cu}_{3} \mathrm{Sn}$ and $\mathrm{Cu}_{6} \mathrm{Sn}_{5}$ were determined by Paul et al. [33], 73.8 and $81 \mathrm{~kJ} \mathrm{~mol}^{-1}$, respectively, whose values were two times higher. Also in the case of Tang et al. [25], the activation energy for $\mathrm{Cu}_{3} \mathrm{Sn}$ phase $90.4 \mathrm{~kJ} \mathrm{~mol}^{-1}$ was almost three times higher than the value obtained in this work, while the value of $41.4 \mathrm{~kJ} \mathrm{~mol}^{-1}$ for $\mathrm{Cu}_{6} \mathrm{Sn}_{5}$ appeared similar. A possible reason for those differences of the discussed results, according to Onishi and Fujibuchi [32], was probably the difference in the measured width of the phases.

Lack of significant differences in the activation energies of the intermetallic layer formation in the $\mathrm{Cu} / \mathrm{Sn}$ and $\mathrm{Cu} /(\mathrm{Sn}+1 \mathrm{at} . \% \mathrm{Ni})$ systems suggests that nickel addition into the tin substrate does not affect the growth rate of $\mathrm{Cu}_{3} \mathrm{Sn}$ and Ni-poor $\left(\mathrm{Cu}_{1-\mathrm{x}} \mathrm{Ni}_{\mathrm{x}}\right)_{6} \mathrm{Sn}_{5}$ phases. The comparison of the microstructure of the reaction zone in the $\mathrm{Cu} / \mathrm{Sn}$ and $\mathrm{Cu} /(\mathrm{Sn}+1$ at.\%Ni) diffusion couples, annealed under the same experimental conditions, is the confirmation of these results (Fig. 11). As it can be seen, the thickness of the phases is more or less the same in both systems. The obtained results clearly suggest that it is very important to which substrate ( $\mathrm{Cu}$ or $\mathrm{Sn}$ ) the nickel is added, especially in the case of the $\left(\mathrm{Cu}_{1-x} \mathrm{Ni}_{\mathrm{x}}\right)_{6} \mathrm{Sn}_{5}$. As was presented previously [17], the addition of $\mathrm{Ni}$ (5 at.\%) into the Cu substrate strongly accelerated the growth of the $\left(\mathrm{Cu}_{1-x} \mathrm{Ni}_{x}\right)_{6} \mathrm{Sn}_{5}$ phase blocking the formation/growth of $\mathrm{Cu}_{3} \mathrm{Sn}$. Also Paul [16] observed that even 1 at.\% of $\mathrm{Ni}$ addition into copper results in increase of the thickness of $\mathrm{Cu}_{6} \mathrm{Sn}_{5}$.

\section{Conclusions}

The presented results showed that the 1 at.\% nickel addition into the tin substrate did not substantially affect the growth of $\mathrm{Cu}_{3} \mathrm{Sn}$ phase, while it strongly influenced the morphology and chemical composition of the $\left(\mathrm{Cu}_{1-x} \mathrm{Ni}_{\mathrm{x}}\right)_{6} \mathrm{Sn}_{5}$ phase. The latter phase occurred in two forms/variants-almost continuous layer and detached irregular grains. The fluctuation of the $\mathrm{Ni}$ concentration in the phase was also observed. The studies of the formation kinetics of the $\mathrm{Cu}_{3} \mathrm{Sn}$ and Ni-poor $\left(\mathrm{Cu}_{1-x} \mathrm{Ni}_{\mathrm{x}}\right)_{6} \mathrm{Sn}_{5}$ phases indicated that the dominating growth mechanism was a volume diffusion process. In the case of the Ni-rich $\left(\mathrm{Cu}_{1-x} \mathrm{Ni}_{x}\right)_{6} \mathrm{Sn}_{5}$ phase, the growth showed a complex mechanism of transport. The comparison of the diffusion coefficients as well as activation energies calculated for $\mathrm{Cu}_{3} \mathrm{Sn}$ and Ni-poor $\left(\mathrm{Cu}_{1-x} \mathrm{Ni}_{x}\right)_{6} \mathrm{Sn}_{5}$ phases with literature data, revealed that the presence of the nickel in the tin substrate did not influence the rate of formation of those phases in comparison with the binary $\mathrm{Cu} / \mathrm{Sn}$ diffusion couples.

\section{Acknowledgements}

This work has been financially supported by the National Science Centre under Grant No. 2011/03/ B/ST8/06158. 


\section{Compliance with ethical standards}

Conflicts of interest Authors declare that no conflicts of interest exist.

Open Access This article is distributed under the terms of the Creative Commons Attribution 4.0 International License (http://creativecommons.org/ licenses/by/4.0/), which permits unrestricted use, distribution, and reproduction in any medium, provided you give appropriate credit to the original author(s) and the source, provide a link to the Creative Commons license, and indicate if changes were made.

\section{References}

[1] Chakrabarti DJ, Laughlin DE, Chen SW, Chang YA (1991) Phase Diagrams of Binary Nickel Alloys. ASM International, Materials Park

[2] Massalski TB, Okamoto H, Subramanian PR, Kacprzak L (1991) Binary Alloy Phase Diagrams. ASM International, Materials Park

[3] Saunders N, Miodownik AP (1990) The Cu-Sn (copper-tin) system. Bull Alloy Phase Diagr 11:278-287

[4] Schmetterer C, Flandorfer H, Richter KW, Saeed U, Kauffman M, Roussel P, Ipser H (2007) A new investigation of the system Ni-Sn. Intermetallics 15:869-884

[5] Nash A, Nash P (1985) The Ni-Sn (Nickel-Tin) System. Bull Alloy Phase Diagr 6:350-359

[6] Ghosh G (1999) Thermodynamic modeling of the nickellead-tin system. Metall Mater Trans 30A:1481-1494

[7] Liu HS, Wang J, Jin ZP (2005) Thermodynamic optimization of the Ni-Sn binary system. Calphad 28:363-370

[8] Huber Z, Wojewoda-Budka J, Wierzbicka-Miernik A, Sypien A, Szczerba M, Zieba P (2016) Influence of phosphorous content on microstructure development at the Ni-P plating/ SAC interface. Electron Mater Lett 12:178-185

[9] Liu B, Tian Y, Liu W, Wu W, Wang C (2016) TEM observation of interfacial compounds of $\mathrm{SnAgCu} / \mathrm{ENIG}$ solder bump after laser soldering and subsequent hot air reflows. Mater Lett 163:254-257

[10] Tseng Ch-F, Duh J-G (2013) Correlation between microstructure evolution and mechanical strength in the $\mathrm{Sn}-3.0 \mathrm{Ag}-0.5 \mathrm{Cu}$ / ENEPIG solder joint. Mat Sci Eng A 580:169-174

[11] Lin HM, Ho CY, Chen WL, Wu YH, Wang DH, Lin JR, Wu YH, Hong HC, Lin ZW, Duh JG (2015) Interfacial reaction and mechanical evaluation in multi-level assembly joints with ENEPIG under bump metallization via drop and high speed impact test. Microelectron Reliab 55:231-237
[12] Cogan SF, Kwon S, Klein JD, Rose RM (1984) Diffusion in the CuSn binary system: application to $\mathrm{Nb}_{3} \mathrm{Sn}$ composites. J Mater Sci 19:497-500

[13] Xia Y, Xie X, Xie X, Lu C (2006) Intermetallic compounds evolution between lead-free solder and cu-based lead frame alloys during isothermal aging. J Mater Sci 41:2359-2364. doi:10.1007/s10853-006-4501-y

[14] Lee YG, Duh JG (1998) Characterizing the formation and growth of intermetallic compound in the solder joint. J Mater Sci 33:5569-5572

[15] Wierzbicka-Miernik A, Wojewoda-Budka J, Litynska-Dobrzynska L, Kodentsov A, Zieba P (2012) Morphology and chemical composition of $\mathrm{Cu} / \mathrm{Sn} / \mathrm{Cu}$ and $\mathrm{Cu}(5 \mathrm{at} \% \mathrm{Ni}) / \mathrm{Sn} /$ $\mathrm{Cu}(5 \mathrm{at} \% \mathrm{Ni})$ interconnections. Sci Technol Weld Joi $17: 32-35$

[16] Paul A (2004) The Kirkendall effect in solid state diffusion, $\mathrm{PhD}$ Dissertation, Eindhoven University of Technology

[17] Wierzbicka-Miernik A, Miernik K, Wojewoda-Budka J, Szyszkiewicz K, Filipek R, Litynska-Dobrzynska L, Kodentsov A, Zieba P (2013) Growth kinetics of the intermetallic phase in diffusion-soldered (Cu-5at.\%Ni)/Sn/ (Cu-5at.\%Ni) interconnections. Mater Chem Phys 142:682685

[18] Wang YW, Chang CC, Kao CR (2009) Thermodynamic Optimization of the Ni-Sn Binary System. J Alloys Compd 478:L1-L4

[19] Romanow P (2007) Microstructural and kinetic characterization of the $\mathrm{Ag} / \mathrm{Sn} / \mathrm{Ag}$ and $\mathrm{Ag} / \mathrm{In} / \mathrm{Ag}$ joints, obtained by low-temperature diffusion soldering, Master Thesis, Institute of Materials Engineering, Cracow University of Technology (in Polish)

[20] Web site: http://rsbweb.nih.gov/ij/

[21] Wierzbicka-Miernik A, Miernik K, Wojewoda-Budka J, Litynska-Dobrzynska L, Garzel G (2015) Microstructure and chemical characterization of the intermetallic phases in $\mathrm{Cu} /$ (Sn, Ni) diffusion couples with various $\mathrm{Ni}$ additions. Intermetallics 59:23-31

[22] Dinsdale AT, Watson A, Kroupa A, Vrestal J, Zemanova A, Vizdal J, Version 3.1 of the "COST531" Database for the lead-free solders

[23] Wierzbicka-Miernik A, Wojewoda-Budka J, Miernik K, Litynska-Dobrzynska L, Schell N (2017) Characteristics of intermetallic phases in $\mathrm{Cu} /(\mathrm{Sn}, \mathrm{Ni})$ diffusion couples annealed at $220{ }^{\circ} \mathrm{C}$. J Alloys Compd 693:1102-1108

[24] Nakayama M, Kajihara M (2014) Kinetics of solid-state reactive diffusion in the $(\mathrm{SnNi}) / \mathrm{Cu}$ system. Mater Trans 55:1266-1273

[25] Tang W, He A, Liu Q, Ivey DG (2010) Solid state interfacial reactions in electrodeposited $\mathrm{Cu} / \mathrm{Sn}$ couples. Trans Nonferrous Met Soc China 20:90-96 
[26] Yuan Y, Guan Y, Li D, Moelans N (2016) Investigation of diffusion behavior in $\mathrm{Cu} / \mathrm{Sn}$ solid state diffusion couples. J Alloys Compd 661:282-293

[27] Crank J (1987) Free and Moving Boundary Problems. Oxford University Press, Oxford

[28] Gupta SC (2003) The stefan problem; basic concepts, modelling and analysis. Elsevier, Amsterdam

[29] Fick AE (1855) Uber Diffusion. Prog Ann 94:59-86

[30] Darken LS (1948) Diffusion, mobility and their interrelation through free energy in binary metallic systems. Trans AIME 175:184-201
[31] Hairer E, Norsett SP, Wanner G (1993) Solving ordinary differential equations I; Nonstiff problems, 2nd edn. Springer, Berlin

[32] Onishi M, Fujibuchi H (1975) Reaction-diffusion in the $\mathrm{Cu}-$ Sn system. Trans Jpn Inst Met 16:539-547

[33] Paul A, Ghosh C, Boettinger WJ (2011) Diffusion Parameters and growth mechanism of phases in the $\mathrm{Cu}-\mathrm{Sn}$ system. Metall Mater Trans A 42A:953-963

[34] Kumar S, Handwerker CA, Dayananda MA (2011) Intrinsic and interdiffusion in $\mathrm{Cu}-\mathrm{Sn}$ system. J Phase Equilib Diff 32:309-319 